\title{
Seeding furrow opening mechanisms and the soybean planting in lowland areas
}

\author{
Lucas Lopes Coelho ${ }^{*}$ Enio Marchesan $^{1}$ Maurício Limberger de Oliveira ${ }^{1}$ (D) \\ Augusto Dubou Serafin ${ }^{1}$ (D) Roberto Paulo Schütz ${ }^{1}$ \\ Camille Flores Soares ${ }^{2}$ Bruno Behenck Aramburu ${ }^{1}$ (D)
}

\footnotetext{
${ }^{1}$ Departamento de Fitotecnia, Centro de Ciências Rurais (CCR), Universidade Federal de Santa Maria (UFSM), 97105-900, Santa Maria, RS, Brasil. E-mail: lucas 1 c@ hotmail.com. "Corresponding author.

${ }^{2}$ Departamento de Fitossanidade, Universidade Federal de Pelotas (UFPel), Pelotas, RS, Brasil.
}

\begin{abstract}
The objective of this research was to evaluate the effect of seeder furrow opening mechanisms on soil physical characteristics, plant growth, and soybean yield in lowland areas with the presence of compacted layer near the surface. An experiment was conducted in the lowland experimental area of the Federal University of Santa Maria-RS, Brazil, during the 2015/16 and 2016/17 growing season. The experimental design was a randomized block with five replications and four treatments: Planter using shank $(S)$ at $0.23 \mathrm{~m}$ depth; $S$ at $0.13 \mathrm{~m}$; Planter using double disk at $0.07 \mathrm{~m}$ depth and Raised-bed $+S$ at $0.12 \mathrm{~m}$ depth. The use of $S$ at $0.23 \mathrm{~m}$ depth allowed reduction of penetration resistance and increase of soil macroporosity in the layers 0-0.1 and 0.1-0.2 $\mathrm{m}$ depth in the seeding row. Sowing with $S$ at 0.23 $\mathrm{m}$ depth and Raised-bed $+S$ at $0.12 \mathrm{~m}$ depth allowed a better development of soybean plants in compacted irrigated rice area (higher nodulation, leaf area index and root growth), as well as higher grain yield.
\end{abstract}

Key words: shank, soil compaction, raised bed, Albaqualf soil, Glycine max.

Mecanismos sulcadores da semeadora e a implantação de soja em área de terras baixas

RESUMO: O trabalho teve como objetivo avaliar o efeito de mecanismos sulcadores da semeadora sobre características fisicas do solo, crescimento de plantas e produtividade de soja em área de terras baixas com presença de camada compactada. Para isso, foi conduzido um experimento na área de várzea da Universidade Federal de Santa Maria, durante as safras agrícolas 2015/16 e 2016/17. O delineamento experimental utilizado foi o de blocos ao acaso, com cinco repetições e quatro tratamentos, sendo eles: Haste sulcadora (HS) a $0.23 \mathrm{~m}$ de profundidade; HS a $0.13 \mathrm{~m}$; Disco duplo a 0.07 m e Microcamalhão + HS a $0.12 \mathrm{~m}$. A utilização da HS a $0.23 \mathrm{~m}$ possibilitou o aumento da macroporosidade e a redução da resistência à penetração mecânica do solo nas camadas de 0-0.1 e 0.1-0.2 m de profundidade na linha de semeadura. A semeadura com HS a 0.23 m e Microcamalhão $+H S$ a $0.12 \mathrm{~m}$ viabilizam melhor desenvolvimento das plantas de soja em área de terras baixas compactada (maior nodulação, índice de área foliar e crescimento radicular), bem como maior produtividade de grãos.

Palavras-chave: haste sulcadora, compactação do solo, microcamalhão, Planossolo, Glycine max.

\section{INTRODUCTION}

The lowland areas of Rio Grande do Sul, Brazil, have been intended for irrigated rice, due to the flat topography and physical characteristics of the soil. However, the high pressure of weeds imposed on the rice created the need to seek alternatives to maintain the profitability of the productive system. In this context, soy appeared as an alternative, since it allowed the use of different active principles of herbicides among other advantages.

However, problems related to the intrinsic characteristics of these soils have been a frequent obstacle to the increment of soybean yield in these areas. The soil cultivated with rice naturally presents unfavorable physical conditions for nonirrigated crops, since they present the formation of a hydromorphic environment with severe restrictions to water drainage, associated with high natural density. These restrictions are aggravated by the intense traffic of agricultural machinery during the preparation of areas for rice cultivation, which often occurs outside the optimal water content (TROYJACK et al., 2019). In this context, the natural characteristics of these soils, associated to the circumstances of the mechanized preparation, generate changes in the porous spaces, causing the phenomenon known as soil compaction (ALAOUI et al., 2011). Among the main consequences of this process, it is possible to mention the reduction of the total porosity (JUNIOR 
et al., 2016), decrease in the continuity and size of porous spaces (BJÖRKLUNDA et al., 2016), reduction of water infiltration capacity (DRESCHER et al., 2017) and the increase in mechanical resistance to penetration (CORTEZ et al., 2014).

In response to changes in physical soil structure, restrictions are imposed on the development of the root system of plants, because the ability of the roots to explore the soil profile reduces when the penetration resistance increases and the aeration porosity decreases (REINERT et al., 2008). SARTORI et al. (2016) mentioned that more than $90 \%$ of the root system of soybeans grown in rotation with rice is concentrated in the depth layer of 0-0.1 m, leaving the crop more prone to water stress, either due to lack or excess of water. Restriction on the growth of the root system of plants, among other parameters, may affect the efficiency of biological nitrogen fixation (AMARANTE \& SODEK, 2006), the stomatal conductance (MADHU et al., 2014), the absorption of water and nutrients, and grain yield (WANG et al., 2019).

Tools that allow the breaking of part of the compacted layer are fundamental for the adequate performance of soybean in these areas. Among the alternatives, it is possible to mention the seeder itself as a means of providing improvements in the root environment. Following SARTORI et al. (2016), the use of a shank in sowing machines in compacted lowland area allowed the development of a superior plant when compared to the double and corrugated disk and can be equated with soil chiseling.

The depth of action of the shank also influences the development of the root system of the plants. According to NUNES et al. (2014), the shank at a depth of $0.17 \mathrm{~m}$ was more efficient in mitigating problems of physical order and chemical stratification when compared to a depth of 0.05 and $0.1 \mathrm{~m}$. Seeding on a raised bed is another alternative, as it creates a faster and more efficient drainage area and makes irrigation possible in periods of water deficiency (RAM et al., 2013). In this context, the objective of this research was to evaluate the effect of seeder furrow opening mechanisms on physical characteristics of soil, plant growth, and soybean yield in lowland areas with the presence of a compacted layer near the surface.

\section{MATERIALS AND METHODS}

The experiment was conducted in the field during the 2015/16 and 2016/17 growing seasons in a systematized lowland area. The site soil is classified as Planossolo Háplico Eutrófico arênico (SANTOS et al., 2013). The allocation of the experiment in the two harvests was carried out in different areas from the experimental station. In the 2015/16 growing season, the soil presented the following physical-chemical characteristics: $\mathrm{MO}=2$ and $1.3 \%$; clay $=26$ and $28 \%$; $\mathrm{pH}$ in water $(1: 1)=6.1$ and 5.1 ; base saturation $=69.9$ and $40.8 \%$; saturation by $\mathrm{Al}=0$ and $1.5 \%$; P-Mehlich= 18.6 and $5.3 \mathrm{mg} \cdot \mathrm{dm}^{-3} ; \mathrm{K}=64$ and $16 \mathrm{mg} \cdot \mathrm{dm}^{-3}$ in the layers of $0-0.1$ and $0.1-0.2 \mathrm{~m}$, respectively. In the $2016 / 17$ growing season, values were: $\mathrm{MO}=2.9$ and $1.9 \%$; clay $=24$ and $26 \%$; $\mathrm{pH}$ in water $(1: 1)=6.2$ and 5.3 ; base saturation $=69.4$ and $42.9 \%$; saturation by $\mathrm{Al}=$ 0 and $6.5 \%$; P-Mehlich $=11.2$ and $6 \mathrm{mg} . \mathrm{dm}^{-3} ; \mathrm{K}=56$ and $16 \mathrm{mg} \cdot \mathrm{dm}^{-3}$. The areas showed that particle density= $2.54 \mathrm{Mg} \cdot \mathrm{m}^{-3}$; field capacity $=0.34 \mathrm{~m}^{-3} \mathrm{~m}^{-3}$ and permanent wilting point $=0.12 \mathrm{~m}^{-3} \mathrm{~m}^{-3}$ in the $0-0.2 \mathrm{~m}$ layer.

A randomized block design with five replications was used, and the experimental units were composed by six rows of sowing, with $90 \mathrm{~m}^{2}$ working areas. The treatments were composed of furrowing mechanisms associated with seeder-fertilizer that are: Planter using shank at $0.13 \mathrm{~m}$ depth; shank at $0.23 \mathrm{~m}$; Planter using double disk at $0.07 \mathrm{~m}$ depth and raisedbed + shank at $0.12 \mathrm{~m}$ depth.

For the implementation of the experiment, a pantographic seeder of the brand Massey Ferguson 407 was used, consisting of six rows spaced at 0.5 $\mathrm{m}$, with a smooth disk diameter of $0.48 \mathrm{~m}$ for straw cutting and an approximate mass of $2.3 \mathrm{Mg}$. For the treatment with the raised seedbed, the pantographic seeder of KF Industrial (Hyper Plus 6/4) was chosen, composed of six rows spaced at $0.5 \mathrm{~m}$, with three moldboards spaced at $1 \mathrm{~m}$ and a mass of $2.9 \mathrm{Mg}$. The mismatched double disks measured at 0.38 and 0.40 $\mathrm{m}$ in diameter, the MF 407 shanks measured 0.43 $\mathrm{m}$ in length, and and angle of attack of $14^{\circ}$. The KF seeder was equipped with a shank of $0.41 \mathrm{~m}$ length, and angle of attack of $17^{\circ}$, which sowed two rows of soybean in each raised bed.

The seeding of the experiment was held on January 4, 2016 (2015/16 growing season) and on November 16, 2016 (2016/17 growing season). In the first growing season, the Nidera 5445 IPRO was used and, in the second, the Syngenta 1562 IPRO was used both with indeterminate growth habit. The seeding density was 32 seeds. $\mathrm{m}^{-2}$. The basic fertilization consisted of $21.5 \mathrm{~kg} \cdot \mathrm{ha}^{-1}$ of N, $86 \mathrm{~kg} \cdot \mathrm{ha}^{-1}$ of $\mathrm{P}_{2} \mathrm{O}_{5}$ and 86 $\mathrm{kg}$.ha ${ }^{-1}$ of $\mathrm{K}_{2} \mathrm{O}$ in the seeding row. In the phenological stadium V6 (FEHR \& CAVINESS, 1977), another 30 kg.ha ${ }^{-1}$ of $\mathrm{K}_{2} \mathrm{O}$ was manually applied.

On the 50th day after seeding, the physical soil variables were determined: density, macroporosity, 
microporosity and total porosity in the seeding row. Undisturbed samples were collected in layers $0-0.1$, $0.1-0.2$ and $0.2-0.3 \mathrm{~m}$ of depth, using rings with 0.04 $\mathrm{m}$ of height and $0.048 \mathrm{~m}$ of diameter, associated to the tension table with $0.6 \mathrm{~m}$ of water column.

The mechanical resistance to root penetration was quantified at 70 days after seeding on the first growing season and to 58 days after seeding on the second. For the evaluation, a digital penetrometer of the brand Falker (model PLG 1020) was used, reaching a depth of $0.3 \mathrm{~m}$. Eight samples were collected for the experimental unit and were arranged parallel to the soybean seeding row as follows: two between the row, one in the row, two between the row, one in the row, and two more between the row.

To evaluate the agronomic performance of the plants, the following variables were determined in the phenological stages: the dry mass of the aerial part, the root system, the nodules and the leaf area index. For this purpose, five plants per experimental unit were collected by removing a soil monolith $(0.5 \times 0.4 \times 0.25 \mathrm{~m}$ of length, width and depth). The aerial part of the root system was then separated. The leaf area index was determined by measuring the length and width of all the central leaflets of each plant trifolium, estimated by the equation $\mathrm{LAI}=2.0185^{*}(\mathrm{C} * \mathrm{~L})$ proposed by RICHTER et al. (2014). To evaluate the dry weight of the nodules, the roots were washed with water to separate from the soil. Afterwards, the nodules and aerial part were dried in an oven with forced ventilation with a temperature of $60{ }^{\circ} \mathrm{C}$.

The effect of the furrow opening mechanisms in the root system of the plants was quantified by determining the length $(\mathrm{cm})$, surface area $\left(\mathrm{cm}^{2}\right)$, volume $\left(\mathrm{cm}^{3}\right)$ and mean diameter $(\mathrm{mm})$ of the roots at the phenological stage R5.1. The same plants from the previous evaluations were used. The cited variables were obtained by scanning the root system in a high resolution scanner (Epson Expression $11000 \mathrm{XL}$ ), with the images processed in the Winrhizo PRO software. The grain yield was determined by hand harvesting in an area of $7.5 \mathrm{~m}^{2}$. After harvesting, the samples were milled, cleaned, weighed and corrected to $13 \%$ moisture, and the data were transformed to $\mathrm{kg} \cdot \mathrm{ha}^{-1}$.

The obtained data were submitted to the presuppositions test of the mathematical model. Analysis of the variance was performed using the $\mathrm{F}$ test. The averages, when significant, were compared by the Scott Knott test, at 5\% probability of error. For physical soil variables (density, macroporosity, microporosity and total porosity), the confidence interval at $5 \%$ probability of error was determined.

\section{RESULTS AND DISCUSSION}

Due to the compaction history of the areas, there was influence of the furrowing mechanisms on the soil's physical parameters (Figures 1, 2 and $3)$. In the $0-0.1 \mathrm{~m}$ depth layer, the systems with the use of the furrowing rod in the deposition of the fertilizer provided an increase of $36 \%$ in the macroporosity when compared to the double disk in the second growing season. The other parameters (density, micorporosity and total porosity) were not significantly affected by the treatments. Therefore, BEUTLER et al. (2012) mentioned that the constant mobilization of the soil for the cultivation of rice provides a lower tendency for compaction in the most superficial layer, making it possible to observe influence of mechanical management on the physical parameters of the soil.

Conversely, because the use of shank at $0.23 \mathrm{~m}$ allowed greater soil mobilization in the $0.1-0.2$ $m$ depth, a reduction of density resulted, presenting values of 1.47 and $1.42 \mathrm{Mg} . \mathrm{m}^{-3}$ for the $2015 / 16$ and $2016 / 17$ seasons, respectively, which on average were $9 \%$ lower than the 1.57 and $1.60 \mathrm{Mg}^{-3} \mathrm{~m}^{-3}$ observed in the double disk system. The macroporosity and total porosity were also influenced by the furrowing mechanisms. In the macroporosity, the shank at $0.23 \mathrm{~m}$ provided an average increase of $41 \%$, when compared to the other treatments (double disk, shank at $0.13 \mathrm{~m}$ and raised bed + shank at $0.12 \mathrm{~m}$ ). Similar results are described by DRESCHER et al. (2017), where the Shank at $0.15 \mathrm{~m}$ resulted in greater total porosity and macroporosity in the $0.07-0.15 \mathrm{~m}$ layer in a compacted Oxisoil, when compared to the double disk and shank at $0.1 \mathrm{~m}$. In relation to microporosity, there was no influence of the treatments in any of the analyzed layers, presenting an average value of 0.34 $\mathrm{m}^{3} \mathrm{~m}^{-3}$. This result was expected, since this property is directly dependent on the soil texture, with little influence by anthropic management (SILVA \& KAY, 1997). In the deepest layer, 0.2-0.3 m, no significant difference was observed for the analyzed variables. These results are due to the fact that none of the treatments tested allowed the full performance of the furrowing mechanisms in this layer. The mean values in the two-year study were $1.59 \mathrm{Mg} . \mathrm{m}^{-3}$, and $0.38,0.33$ and $0.05 \mathrm{~m}^{3} \mathrm{~m}^{-3}$ for density, total porosity, microporosity and macroporosity, respectively.

Resistance to root penetration was determined when the soil had a volumetric moisture 


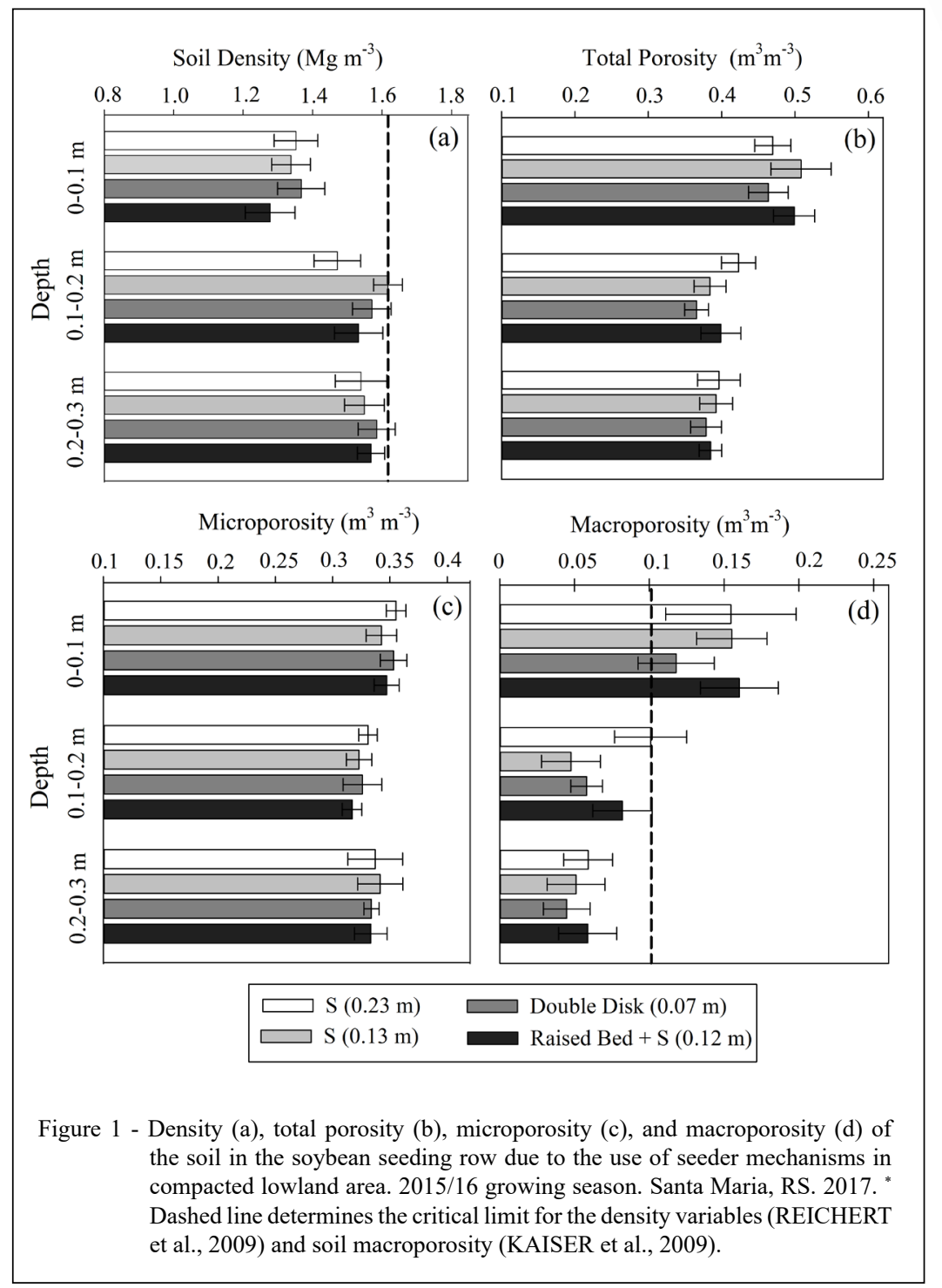

of 0.29 and $0.24 \mathrm{~m}^{3} \mathrm{~m}^{-3}$ in the $0-0.3 \mathrm{~m}$ layer at 2015/16 and 2016/17 growing seasons, respectively. As shown in figure 3, the conduction areas of the experiment presented resistance to penetration higher than $2 \mathrm{MPa}$ at $0.08 \mathrm{~m}$ of depth in the first growing season and $0.05 \mathrm{~m}$ in the second. As a result, the shank at $0.23 \mathrm{~m}$ was the most efficient in the decompression of the soil at the seeding row, where the penetration resistance did not exceed 1 $\mathrm{MPa}$ for up to $0.2 \mathrm{~m}$ depth. For the treatment with shank at $0.13 \mathrm{~m}$, the same tendency is observed, with reduction of the compaction up to the depth of actuation of the mechanism (Figure $1 \mathrm{~B}$ and $1 \mathrm{~F}$ ). In contrast, the double disk practically did not alter the original structure of the soil, being inefficient in the mitigation of physical problems in the seeding row.

The magnitude of the benefits derived from the use of shanks in the rupture of the compacted layer is dependent on several factors. Among them are the intrinsic characteristics of the soil, the type of mechanism used and especially the depth of action (DRESCHER et al., 2017), since the mobilization of the soil allows the reduction of the density, which along with moisture, determines the degree of mechanical resistance to root penetration.

As the variables analyzed in the soil, the root systems of the plants were also influenced by the treatments in both harvests (Table 1). The double disk 


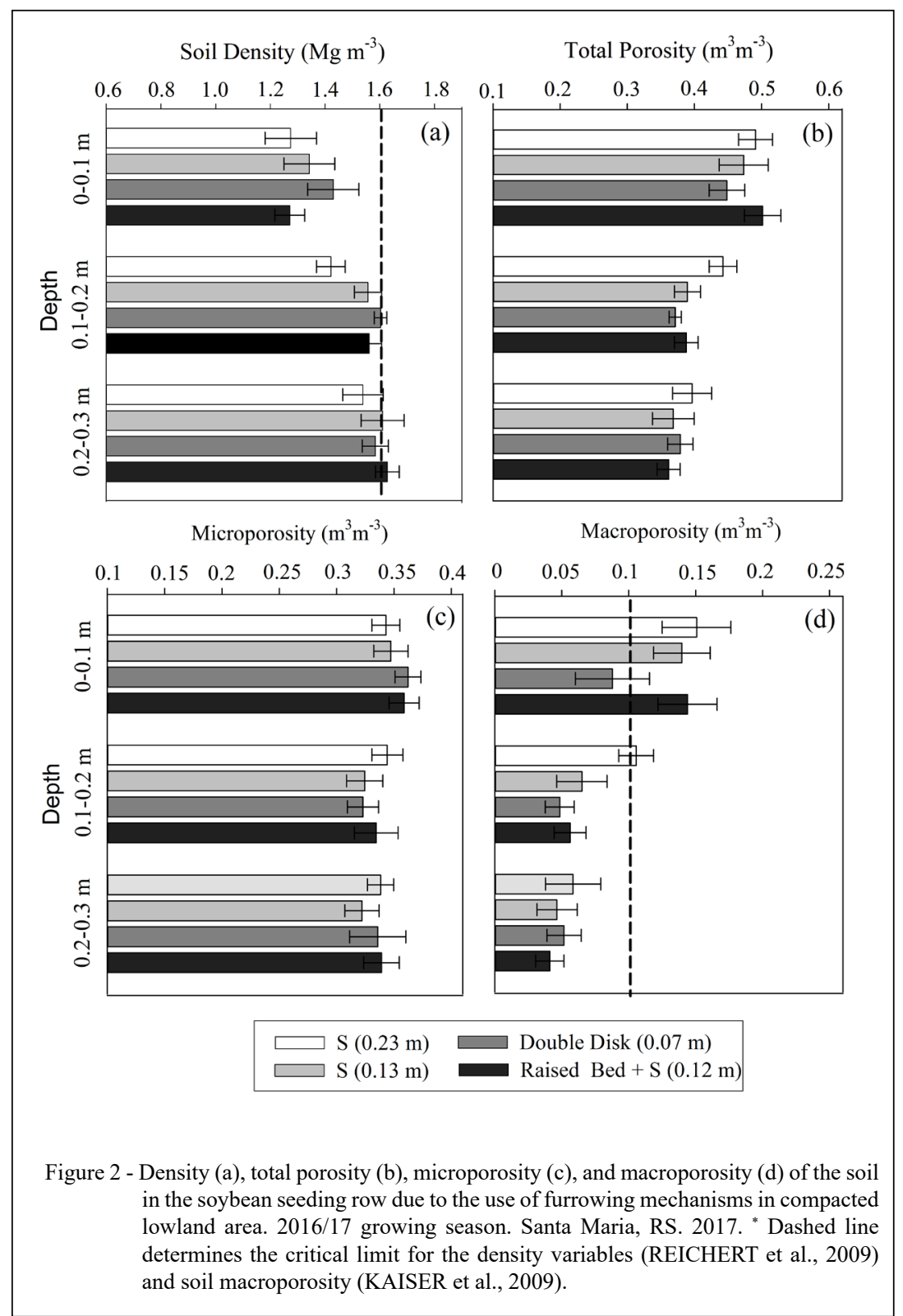

caused the reduction of the dry mass of roots by 36 and $23 \%$ in the phenological stadiums V7 and R5.1, when compared to the average of treatments with shank at $0.23 \mathrm{~m}$ and raised bed + shank at $0.12 \mathrm{~m}$. The same trend was observed for the data obtained by the Winrhizo software (Table 1), where, in the R5.1 stadium, the reduction was 45,42 and $36 \%$ for length, surface area and root volume, respectively. These results are in agreement with those obtained by SARTORI et al. (2016), where the use of the double disk generated a significant reduction in root development when compared to systems that allowed greater soil mobilization. Thus, it can be observed that the root development was directly proportional to the capacity of each of the furrowing mechanisms in breaking the compacted soil layer, and to allow a more efficient drainage in the zone of greater growth of the roots. 


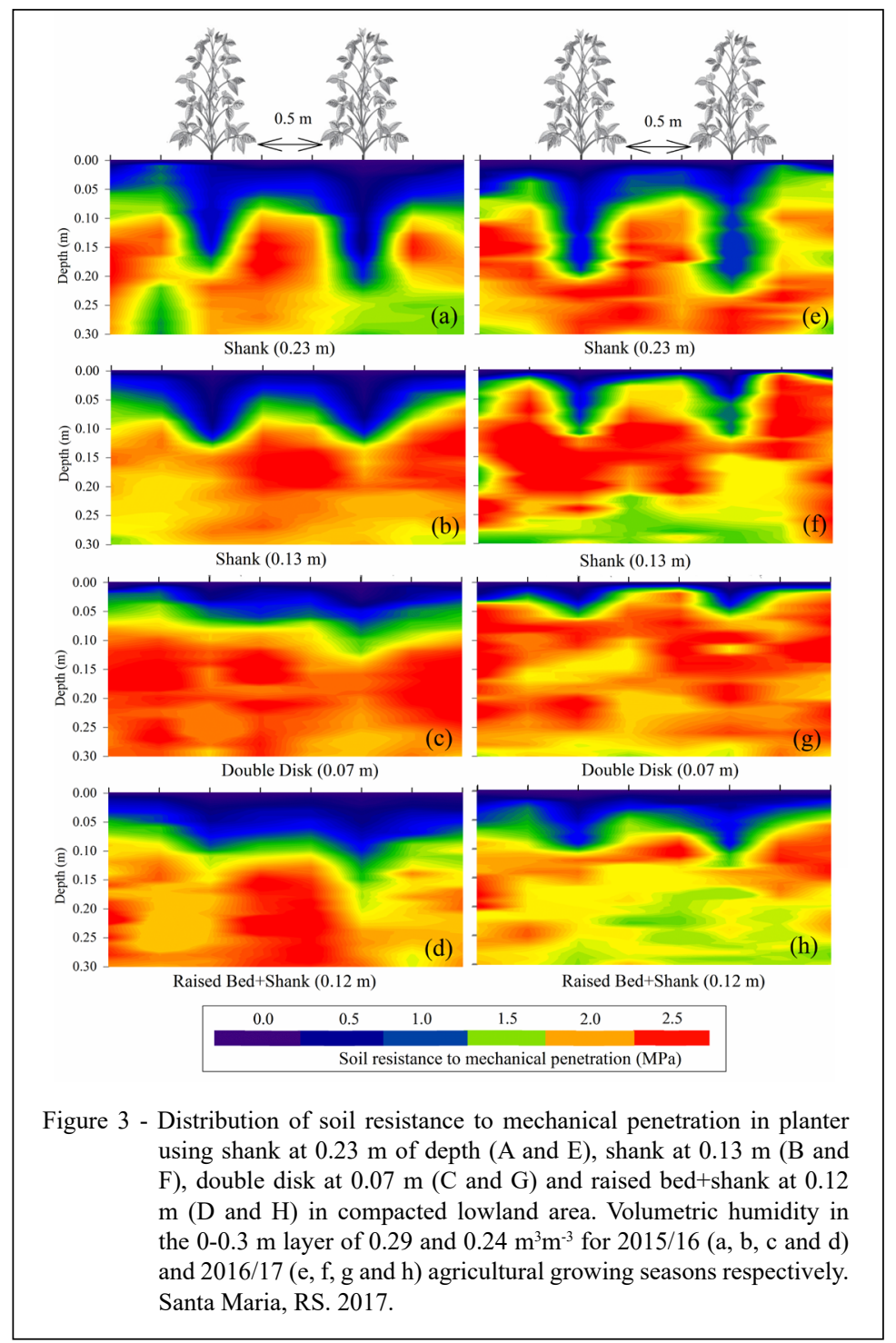

Soil compaction exerts significant changes in the morphology as well as in the growth of the root system of soybean plants (RAMOS et al., 2010). REINERT et al. (2008) cited that the ability of roots to explore the soil profile reduced when penetration resistance and density increased. The root elongation is dependent on the hydrostatic pressure inside the root, which has to be greater than the pressure exerted by the soil for its expansion (HAMZA \& ANDERSON, 2005). Therefore, values of penetration resistance greater than $2 \mathrm{MPa}$ are considered limiting to the adequate development of roots (LIMA et al., 2010), as well as densities above $1.6 \mathrm{Mg}^{-3} \mathrm{~m}^{-3}$, due to the soil clay content (REICHERT et al., 2009). These values were already reported from $0.1 \mathrm{~m}$ of depth on the double disc. In addition, with the exception of shank at $0.23 \mathrm{~m}$, it was reported that in the 0.1-0.2 m layer, the soil macroporosity has always been below $0.1 \mathrm{~m}^{3} \mathrm{~m}^{3}$. According to KAISER et al. (2009), values below this critical point are considered restrictive to root growth, since this parameter is directly related to the diffusion of oxygen and $\mathrm{CO}_{2}$ in the soil, thus determining the soil aeration capacity.

The initial population of plants was similar among treatments at both growing seasons analyzed. For the dry mass of the aerial part, the treatments with shank at $0.23 \mathrm{~m}$ and raised bed + shank at 0.12 $\mathrm{m}$ (Table 2) presented the highest values in the V7 and R5.1 phenological stadiums in the two growing seasons analyzed, and did not differ statistically from 
Table 1 - Initial plant population (IPP), aerial dry mass (ADM) and root dry mass (RDM) of the soybean in the phenological stages V7 and R5.1, and length (L), surface area (SA), relative volume (RV) and mean diameter (MD) of the soybean roots at the phenological stage R5.1 as a function of the use planter furrowing mechanisms in the compacted lowland area. Santa Maria, RS. 2017.

\begin{tabular}{|c|c|c|c|c|c|}
\hline \multirow[t]{3}{*}{ Treatments } & \multicolumn{5}{|c|}{ 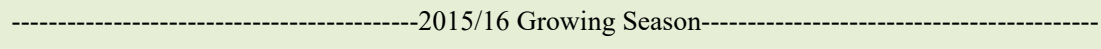 } \\
\hline & \multirow[t]{2}{*}{ IPP (plants.m-2) } & \multicolumn{2}{|c|}{--------ADM (g.plant-1)-------- } & \multicolumn{2}{|c|}{------------RDM (g.plant-1)----------- } \\
\hline & & V7 & R5.1 & V7 & R5.1 \\
\hline $\mathrm{S}(0.23 \mathrm{~m})$ & $26.0 \mathrm{~ns}$ & $6.9 \mathrm{a}^{*}$ & $17 \mathrm{a}$ & $1.6 \mathrm{a}$ & $3.1 \mathrm{a}$ \\
\hline $\mathrm{S}(0.13 \mathrm{~m})$ & 25.8 & $6.4 \mathrm{a}$ & $16.1 \mathrm{a}$ & $1.5 \mathrm{a}$ & $2.9 \mathrm{~b}$ \\
\hline Double Disk (0.07 m) & 25.0 & $3.8 \mathrm{~b}$ & $12.1 \mathrm{~b}$ & $1.0 \mathrm{~b}$ & $2.5 \mathrm{~b}$ \\
\hline Raised bed $+\mathrm{S}(0.12 \mathrm{~m})$ & 25.4 & $7.6 \mathrm{a}$ & $18.9 \mathrm{a}$ & $1.7 \mathrm{a}$ & $3.5 \mathrm{a}$ \\
\hline Mean & 25.5 & 6.2 & 16.0 & 1.5 & 3.0 \\
\hline \multirow[t]{2}{*}{$\mathrm{CV}(\%)$} & 10.3 & 14.6 & 11.3 & 9.5 & 12.9 \\
\hline & $\mathrm{L}(\mathrm{cm})$ & \multicolumn{2}{|c|}{$\mathrm{SA}(\mathrm{cm} 2)$} & $\mathrm{RV}(\mathrm{cm} 3)$ & $\mathrm{MD}(\mathrm{mm})$ \\
\hline $\mathrm{S}(0.23 \mathrm{~m})$ & $2903 \mathrm{a}^{*}$ & \multicolumn{2}{|c|}{$431.9 \mathrm{~b}$} & $5.19 \mathrm{~b}$ & $0.472 \mathrm{c}$ \\
\hline $\mathrm{S}(0.13 \mathrm{~m})$ & $2484 \mathrm{~b}$ & \multicolumn{2}{|c|}{$393.2 \mathrm{~b}$} & $5.03 \mathrm{~b}$ & $0.506 \mathrm{~b}$ \\
\hline Double Disk $(0.07 \mathrm{~m})$ & $1382 \mathrm{c}$ & \multicolumn{2}{|c|}{$242.3 \mathrm{c}$} & $3.42 \mathrm{c}$ & $0.558 \mathrm{a}$ \\
\hline Raised bed $+\mathrm{S}(0.12 \mathrm{~m})$ & $3212 \mathrm{a}$ & \multicolumn{2}{|c|}{$502 \mathrm{a}$} & $6.44 \mathrm{a}$ & $0.498 \mathrm{~b}$ \\
\hline Mean & 2495.2 & \multicolumn{2}{|c|}{392.4} & 5.02 & 0.509 \\
\hline CV $(\%)$ & 10.8 & \multicolumn{2}{|c|}{13.4} & 11.6 & 3.4 \\
\hline \multirow[t]{3}{*}{ Treatments } & \multicolumn{5}{|c|}{ 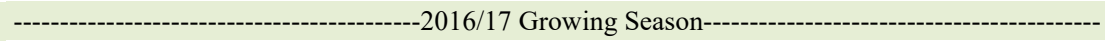 } \\
\hline & \multirow[t]{2}{*}{ IPP (plants.m-2) } & \multicolumn{2}{|c|}{---------ADM (g.plant-1)-------- } & \multicolumn{2}{|c|}{------------RDM (g.plant-1)------------ } \\
\hline & & V7 & R5.1 & V7 & R5.1 \\
\hline $\mathrm{S}(0.23 \mathrm{~m})$ & $26.7 \mathrm{~ns}$ & $7.4 \mathrm{a}$ & $27.6 \mathrm{a}$ & $1.8 \mathrm{a}$ & $5.2 \mathrm{a}$ \\
\hline $\mathrm{S}(0.13 \mathrm{~m})$ & 26.1 & $6.0 \mathrm{a}$ & $20.1 \mathrm{~b}$ & $1.4 \mathrm{~b}$ & $4.3 \mathrm{~b}$ \\
\hline Double Disk (0.07 m) & 27.8 & $4.7 \mathrm{~b}$ & $15.9 \mathrm{~b}$ & $1.3 \mathrm{~b}$ & $4.2 \mathrm{~b}$ \\
\hline Raised bed $+\mathrm{S}(0.12 \mathrm{~m})$ & 25.5 & $6.8 \mathrm{a}$ & $25.7 \mathrm{a}$ & $1.9 \mathrm{a}$ & $5.8 \mathrm{a}$ \\
\hline Mean & 26.5 & 6.2 & 22.3 & 1.6 & 4.9 \\
\hline \multirow[t]{2}{*}{$\mathrm{VC}(\%)$} & 6.2 & 13.0 & 17.6 & 9.5 & 15.5 \\
\hline & $\mathrm{L}(\mathrm{cm})$ & \multicolumn{2}{|c|}{$\mathrm{SA}(\mathrm{cm} 2)$} & $\mathrm{V}(\mathrm{cm} 3)$ & $\mathrm{MD}(\mathrm{mm})$ \\
\hline $\mathrm{S}(0.23 \mathrm{~m})$ & 3036 a & \multicolumn{2}{|c|}{$349.2 \mathrm{a}$} & $3.21 \mathrm{~b}$ & $0.366 \mathrm{~ns}$ \\
\hline $\mathrm{S}(0.13 \mathrm{~m})$ & $2519 \mathrm{~b}$ & \multicolumn{2}{|c|}{$305.7 \mathrm{~b}$} & $3.03 \mathrm{~b}$ & 0.390 \\
\hline Double Disk (0.07 m) & $2010 \mathrm{~b}$ & \multicolumn{2}{|c|}{$241.5 \mathrm{~b}$} & $2.54 \mathrm{c}$ & 0.382 \\
\hline Raised bed $+\mathrm{S}(0.12 \mathrm{~m})$ & $3175 \mathrm{a}$ & \multicolumn{2}{|c|}{$373.8 \mathrm{a}$} & $3.82 \mathrm{a}$ & 0.378 \\
\hline Mean & 2684.8 & \multicolumn{2}{|c|}{317.6} & 3.15 & 0.379 \\
\hline CV (\%) & 19.6 & \multicolumn{2}{|c|}{14.9} & 8.9 & 4.7 \\
\hline
\end{tabular}

ns Not significant:; ${ }^{*}$ Means not followed by the same letter differ from each other by the Scott-Knott test at $5 \%$ probability. (S 0.23 m) shank at $0.23 \mathrm{~m}$ depth; ( $0.13 \mathrm{~m}$ ) shank at $0.13 \mathrm{~m}$ depth; (Raised bed+S $0.12 \mathrm{~m}$ ) Raised bed associated to shank at depth of $0.12 \mathrm{~m}$.

$\mathrm{S}$ at $0.13 \mathrm{~m}$ in the first year. In addition, the lowest nodule of dry mass was verified with the double disk in all evaluations performed, where at the R5.1 stage, the reduction reached $65 \%$ when compared to raised bed + shank at $0.12 \mathrm{~m}$. For the leaf area index, the same tendency of the variable of the nodule dry mass was observed.

These results are a reflection of the ability of each furrowing mechanism to mitigate soil compaction losses on the plants. According to BEUTLER et al. (2012), the physical impediment to root growth associated with deficient aeration results in the reduction of water and nutrient absorption capacity. The restriction to the growth of the root system also causes an increase in abscisic acid (ABA) production in the roots, which, when exported to the aerial part of the plants, is responsible for the reduction of stomatal conductance, photosynthetic capacity and consequently, leaf expansion (TAIZ \& ZEIGER, 2013). In addition, nodulation may also be affected by $\mathrm{O}_{2}$ in soils with low macroporosity and difficult drainage. This fact is due to the key 
Table 2 - Leaf area index (LAI) and nodules dry mass (NDM) at V7 and R5.1 phenological stadiums, number of pods per plant (NPP) and grain yield of the soybean due to the use of planter furrowing mechanisms in compacted lowland area. Santa Maria, RS. 2017.

\begin{tabular}{|c|c|c|c|c|c|c|}
\hline \multirow[t]{3}{*}{ Treatments } & \multicolumn{6}{|c|}{ 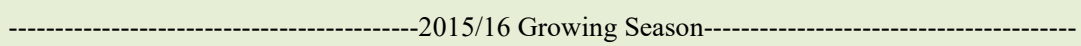 } \\
\hline & \multicolumn{2}{|c|}{-------LAI (m2.m-2)-------- } & \multicolumn{2}{|c|}{--------NDM (g.plant1)------ } & \multirow[t]{2}{*}{ NPP } & \multirow[t]{2}{*}{ Yield (kg.ha-1) } \\
\hline & V7 & R5.1 & V7 & R5.1 & & \\
\hline $\mathrm{S}(0.23 \mathrm{~m})$ & $2.37 \mathrm{a}^{*}$ & $4.11 \mathrm{a}$ & $0.241 \mathrm{a}$ & $0.789 \mathrm{a}$ & $38.8 \mathrm{a}$ & 3440 a \\
\hline $\mathrm{S}(0.13 \mathrm{~m})$ & $2.16 \mathrm{a}$ & $3.80 \mathrm{a}$ & $0.239 \mathrm{a}$ & $0.800 \mathrm{a}$ & $34.6 \mathrm{~b}$ & $3197 \mathrm{~b}$ \\
\hline Double Disk (0.07 m) & $1.36 \mathrm{~b}$ & $2.70 \mathrm{~b}$ & $0.123 \mathrm{~b}$ & $0.562 \mathrm{~b}$ & $31.2 \mathrm{~b}$ & $2991 \mathrm{~b}$ \\
\hline Raised bed $+\mathrm{S}(0.12 \mathrm{~m})$ & $2.49 \mathrm{a}$ & $4.19 \mathrm{a}$ & $0.200 \mathrm{a}$ & $0.854 \mathrm{a}$ & $38.6 \mathrm{a}$ & 3513 a \\
\hline Mean & 2.09 & 3.70 & 0.201 & 0.751 & 35.8 & 3285 \\
\hline CV $(\%)$ & 9.1 & 14.5 & 21.1 & 10.2 & 10.2 & 6.4 \\
\hline \multirow[t]{3}{*}{ Treatments } & \multicolumn{6}{|c|}{-----------------------------------------2016/17 Growing Season--------------------------------------------- } \\
\hline & \multicolumn{2}{|c|}{--------LAI (m2.m-2)-------- } & \multicolumn{2}{|c|}{-------NDM (g.plant-1)------ } & NPP & \multirow{2}{*}{ Yield (kg.ha-1) } \\
\hline & V7 & R5.1 & V7 & R5.1 & & \\
\hline $\mathrm{S}(0.23 \mathrm{~m})$ & $2.73 \mathrm{a}$ & $6.18 \mathrm{a}$ & $0.288 \mathrm{a}$ & $1.401 \mathrm{a}$ & $54.1 \mathrm{a}$ & $4563 \mathrm{a}$ \\
\hline $\mathrm{S}(0.13 \mathrm{~m})$ & $1.79 \mathrm{~b}$ & $4.48 \mathrm{~b}$ & $0.215 \mathrm{~b}$ & $0.983 \mathrm{~b}$ & $43.1 \mathrm{~b}$ & $3976 \mathrm{~b}$ \\
\hline Double Disk $(0.07 \mathrm{~m})$ & $1.52 \mathrm{~b}$ & $4.07 \mathrm{~b}$ & $0.137 \mathrm{c}$ & $0.946 \mathrm{~b}$ & $43.1 \mathrm{~b}$ & $3504 \mathrm{c}$ \\
\hline Raised bed $+\mathrm{S}(0.12 \mathrm{~m})$ & $2.11 \mathrm{~b}$ & $5.76 \mathrm{a}$ & $0.203 \mathrm{~b}$ & $1.472 \mathrm{a}$ & $59.6 \mathrm{a}$ & 4329 a \\
\hline Mean & 2.04 & 5.12 & 0.211 & 1.20 & 50.0 & 4093 \\
\hline $\mathrm{CV}(\%)$ & 17.4 & 16.7 & 16.2 & 14.0 & 8.9 & 6.1 \\
\hline
\end{tabular}

${ }^{*}$ Means not followed by the same letter differ from each other by the Scott-Knott test, at $5 \%$ probability. (S $\left.0.23 \mathrm{~m}\right)$ shank at $0.23 \mathrm{~m}$ depth; (S $0.13 \mathrm{~m}$ ) shank at $0.13 \mathrm{~m}$ depth; (Raised bed+S $0.12 \mathrm{~m}$ ) Raised bed associated to shank at depth of $0.12 \mathrm{~m}$.

process of reducing atmospheric nitrogen to nitrate being catalyzed by the enzyme nitrate reductase, which is extremely sensitive to low levels of $\mathrm{O}_{2}$ in the soil (AMARANTE \& SODEK, 2006). Biological nitrogen fixation is a metabolic process of high energy demand, requiring 16 ATPs for the complete reduction of a molecule of $\mathrm{N}_{2}$ to $\mathrm{NH}_{3}$ (TAIZ \& ZEIGER, 2013). Thus, the concentration of $\mathrm{O}_{2}$ at appropriate levels in the bacteroid zone is fundamental for the maintenance of cellular respiration.

The improvement in the physical attributes of the soil and consequently, of the development of plants is reflected in the productivity of grains. The shank treatments at $0.23 \mathrm{~m}$ and raised bed + shank at $0.12 \mathrm{~m}$ presented the highest yields in the two growing seasons analyzed, and did not differ statistically among themselves. In the first one, the use of the double disk and the shank at $0.13 \mathrm{~m}$ resulted in the reduction of 385 and $279 \mathrm{~kg} \cdot \mathrm{ha}^{-1}$, respectively, when compared to the average of the treatments with higher productivity. In the 2016/17 growing season, the same tendency is observed; however, with larger reductions, reaching 942 and $470 \mathrm{~kg} \cdot \mathrm{ha}^{-1}$. The highest average yield (4093 kg.ha-1) verified in the 2016/17 growing season can be explained by the date of seeding, where, in the first year, it was held out of the preferential season $(04 / 01 / 2016)$, thus losing productive potential.

In general, it can be observed that the physical limitations of the soil impaired the development of the plants. The shank at $0.23 \mathrm{~m}$, due to reducing the effects of compaction in the sowing row, allowed a greater growth of the root system of the plants, which is directly responsible for overcoming the frequent period of hydrical stress that occur in these areas. As a consequence, this treatment enabled higher LAI and MDN, which are factors considered crucial in obtaining high productivity. In addition, both growing seasons analyzed presented elevated rainfall during the development of the crop, with $562 \mathrm{~mm}$ in the 2015/16 and $918 \mathrm{~mm}$ in the 2016/17 growing season. From this perspective, the raised bed $+\mathrm{S}(0.12 \mathrm{~m})$ made a faster and more efficient drainage of the area possible due to the construction of the "micro-drainages".

\section{CONCLUSION}

The shank at $0.23 \mathrm{~m}$ depth provided the increase of macroporosity and the reduction of the mechanical resistance to the penetration of the soil in the seeding row, in the 0-0.2 m layer. 
The seeding with a $0.23 \mathrm{~m}$ shank and a raised bed+ shank at $0.12 \mathrm{~m}$ allowed a higher yield of soybean grains in lowland areas with a compacted layer close to the soil surface.

\section{ACKNOWLEDGEMENTS}

We would like to thank the Coordenação de Aperfeiçoamento Pessoal de Nível Superior (CAPES), Brasil Finance code 001, for the doctoral scholarship granted to the first author. We also thank the Conselho Nacional de Desenvolvimento Científico e Tecnológico (CNPq) for granting the research productivity scholarship to the second author.

\section{DECLARATION OF CONFLICT OF INTEREST}

The authors declare no conflict of interest. The founding sponsors had no role in the design of the study; in the collection, analyses, or interpretation of data; in the writing of the manuscript, and in the decision to publish the results.

\section{AUTHORS' CONTRIBUTIONS}

The authors also contributed to the manuscript.

\section{REFERENCES}

ALAOUI, A. et al. A review of the changes in the soil pore system due to soil deformation: A hydrodynamic perspective. Soil and Tillage Research, v.115, p.1-15, 2011. Available from: <https:// www.sciencedirect.com/science/article/pii/S0167198711001139>. Accessed: Jun. 18, 2017. doi: 10.1016/j.still.2011.06.002.

AMARANTE, L.; SODEK, L. Waterlogging effect on xylem sap glutamine of nodulated soybean. Biologia Plantarum, v.50, p.405410, 2006. Available from: <https://link.springer.com/content/ pdf/10.1007\%2Fs10535-006-0057-6.pdf>. Accessed: May. 20, 2017. doi: 10.1007/s10535-006-0057-654.

BEUTLER, A.N. et al. Soil physical properties and rice straw levels in management systems: effect on irrigated rice yield. Revista Brasileira de Ciência do Solo, v.36, p.1601-1607, 2012. Available from: <http://www.scielo.br/pdf/rbcs/v36n5/24.pdf >. Accessed: Jun. 05, 2017. doi: 10.1590/S0100-06832012000500024.

BJÖRKLUNDA, M.M. et al. Effects of subsoil compaction on hydraulic properties and preferential flow in a Swedish clay soil. Soil and Tillage Research, v.156, p.91-98, 2016. Available from: $\quad<$ https://www.sciencedirect.com/science/article/pii/ S0167198715300301>. Accessed: May, 22, 2017. doi: 10.1016/j. still.2015.09.013.

CORTEZ, J.W. et al. Evaluation the intensity of tractor traffic on some physical properties of an argissolo amarelo (ultisol). Revista Brasileira de Ciência do Solo, v.38, p.1000-1010, 2014. Available from: <http://www.scielo.br/pdf/rbcs/v38n3/32.pdf $>$. Accessed: May, 22, 2017. doi: 10.1590/S0100-06832014000300032.

DRESCHER, M.S. et al. Fertilizer shanks to promote soil decompaction in the seeding operation. Ciência Rural, v.47, 2017. Available from: <http://www.scielo.br/pdf/cr/v47n3/1678- 4596-cr-47-03-e20160026.pdf>. Accessed: Jun. 05, 2017. doi: $10.1590 / 0103-8478 \mathrm{cr} 20160026$

FEHR, W.R.; CAVINESS, C.E. Stages of soybean development Ames: State University of Science and Technology, p.1-11, 1977. (Special report, 80).

HAMZA, M.A.; ANDERSON, W.K. Soil compaction in cropping systems: A review of the nature, causes and possible solutions. Soil \& Tillage Research, v.82, p.121-145, 2005. Available from: $\quad<$ https://www.sciencedirect.com/science/article/pii/ S0167198704001849>. Accessed: Jun. 25, 2017. doi: 10.1016/j. still.2004.08.009.

JUNIOR, M.A.D. et al. Tillage machinery and compaction level influence on soil physical properties and corn agronomic aspects. Engenharia Agrícola, v.36, p.367-376, 2016. Available from: <http://www.scielo.br/pdf/eagri/v36n2/18094430-eagri-36-2-0367.pdf>. Accessed: May 18, 2017. doi: $10.1590 / 1809-4430$

KAISER, D.R. et al. Least limiting water range in an oxisol profile penetrated by common bean roots under different compaction levels. Revista Brasileira de Ciência do Solo, v.33, p.845855, 2009. Available from: <http://www.scielo.br/pdf/rbcs/ v33n4/09.pdf>. Accessed: Jun. 25, 2017. doi: 10.1590/S010006832009000400009.

LIMA, C.L.R. et al. Yield of crops and soil resistance to penetration of the alfisol under different management. Pesquisa Agropecuária Brasileira, v.45, p.89-98, 2010. Available from: <http://www. scielo.br/pdf/pab/v45n1/a12v45n1.pdf>. Accessed: Jul. 02, 2017. doi: 10.1590/S0100-204X2010000100012.

MADHU, M.; HATFIELD, J.L. Interaction of carbon dioxide enrichment and soil moisture on photosynthesis, transpiration, and water use efficiency of soybean. Agricultural Sciences, v.5, p.410-429, 2014. Available from: <http://file.scirp.org/pdf/ AS 2014040911594474.pdf>. Accessed: Jun. 20, 2017. doi: $10.4236 /$ as. 2014.55043

NUNES, M.R. et al. Effect of seed drill with fixed shanks for deep action in soil under no-till. Revista Brasileira de Ciência do Solo, v.38, p.627-638, 2014. Available from: <http://www.scielo.br/ pdf/rbcs/v38n2/27.pdf $>$. Accessed: May 28, 2017. doi: 10.1590/ S0100-06832014000200027.

RAM, Y.S. et al. Tillage and planting methods effects on yield, water use efficiency and profitability of soybean-wheat system on a loamy sand soil by hari. Experimental Agriculture, v.49, p.524-542, 2013. Available from: <https:/www.researchgate.net/ publication/255792442 Tillage and planting methods effect on_yield_water_use_efficiency_and_profitability_of_soybean wheat system on a loamy sand soil >. Accessed: May. 28, 2017. doi: $10.1017 / \mathrm{s} 0014479713000264$.

RAMOS, J.C. et al. Morphological characteristics of soybean root apexes as indicators of soil compaction. Scientia Agrícola, v.67, p.707-712, 2010. Available from: <http://www.scielo.br/pdf/sa/ v67n6/v67n6a13.pdf>. Accessed: May 15, 2017. doi: 10.1590/ S0103-90162010000600013.

REICHERT, J.M. et al. Reference bulk density and critical degreeof-compactness for no-till crop production in subtropical highly weathered soils. Soil and Tillage Research, v.102, p.242254, 2009. Available from: <https://www.sciencedirect.com/ 
science/article/pii/S0167198708001025>. Accessed: Jul. 04, 18, 2002. doi: $10.1016 /$ j.still.2008.07.002.

REINERT, D.J. et al. Bulk density critical limits for normal root growth of cover crops. Revista Brasileira de Ciência do Solo, v.32, p.1805-1816, 2008. Available from: <http://www.scielo.br/ $\mathrm{pdf} / \mathrm{rbcs} / \mathrm{v} 32 \mathrm{n} 5 / 02 . \mathrm{pdf}>$. Accessed: Mar. 18, 2002. doi: 10.1590/ S0100-06832008000500002.

RICHTER, G.L. et al. Estimating leaf area of modern soybean cultivars by a non-destructive method. Bragantia, v.73, p.416-425, 2014 Available from: <http://www.scielo.br/pdf/brag/v73n4/a10v73n4. pdf $>$. Accessed: Ago. 25, 2015. doi: 10.1590/1678-4499.0179.

SANTOS, H.G. et al. Sistema brasileiro de classificação de solos. 3a ed rev. ampl. Rio de Janeiro: Embrapa Solos, 2013. 353p.

SARTORI, G.M.S. et al. Growth and development of soybean roots according to planting management systems and irrigation in lowland areas. Ciência Rural, v.46, p.1572-1578, 2016. Available from: <http://www.scielo.br/pdf/cr/v46n9/1678-4596cr-46-09-01572.pdf $>$. Accessed: Mar. 15, 2017. doi: 10.1590/0103$8478 \mathrm{cr} 20151579$.
SILVA, A.P. da; KAY, B.D. Estimating the least limiting water range of soils from properties and management. Soil Science Society of America Journal, v.61, p.877-883, 1997. Available from: < https://dl.sciencesocieties.org/publications/sssaj/pdfs/61/3/ SS0610030877>. Accessed: May 05, 2017. doi: 10.2136/sssaj1997 $.03615995006100030023 \mathrm{x}$.

TAIZ, L.; ZEIGER, E. Plant Physiology and Development. 6. ed. Porto Alegre: Artmed. p.858, 2017.

TROYJACK, C. et al. Diversification of Crops and Conservation Management in Lowland Soils of Rio Grande do Sul. Journal of Agricultural Science, v.11, n.12, 2019. Available from:<https://pdfs.semanticscholar.org/76ae/03edd e43cfa6bad6317a36ecdaa95bb0318e.pdf $>$. Accessed: Sep. 21, 2019. doi: $10.5539 /$ jas.v11n12p1.

WANG, M. et al. Effects of soil compaction on plant growth, nutrient absorption, and root respiration in soybean seedlings. Environmental Science and Pollution Research, v.26, p.22835-22845, 2019. Available from: <https://link.springer.com/ article/10.1007/s11356-019-05606-z >. Accessed: Sep. 21, 2019. doi:10.1007/s11356-019-05606-z. 